\title{
Puesta en valor del Parque Santa Teresa como paisaje cultural. Proyecto y Ordenamiento del Paisaje en los Lineamientos generales de su Plan Director
}

SELECCIÓN IX SEMINARIO INTERNACIONAL DE INVESTIGACIÓN EN URBANISMO Barcelona \& Bogotá, jun. 2017.

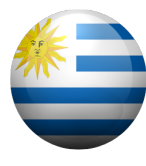
Nair Rosana Sommaruga Montiel

Coordinadora Académica del Programa de Investigación “Paisaje y Espacio Público", Directora Académica del Diploma de Especialización en Proyecto de Paisaje. Instituto de Diseño de la Facultad de Arquitectura Diseño y Urbanismo, Universidad de la República. Montevideo [Montevideo] Uruguay. <rsommaruga@gmail.com>

Publicado em: https://upcommons.upc.edu/handle/2117/108546

\section{Resumen}

La ponencia constituye una síntesis de los estudios paisajísticos desarrollados en el marco del asesoramiento "Lineamientos generales para el Plan Director del Parque Santa Teresa", Convenio realizado entre el Ministerio de Turismo (MINTUR) y la Facultad de Arquitectura, Diseño y Urbanismo (FADU) de la Universidad de la República (UDELAR) entre agosto de 2015 y julio de 2016. El objeto del Convenio es posicionar al Parque Santa Teresa como "parque modelo" para el Uruguay todo, poniendo en valor sus características patrimoniales, paisajísticas y medioambientales, coadyuvando así a su promoción turística y socio-cultural. El trabajo general conjuga distintos estudios disciplinares y aportes externos. El programa de Investigación "Paisaje y Espacio Público" del Instituto de Diseño (IdD) en colaboración con VIDIALAB desarrolla la Caracterización y Valoración Paisajística del Parque, a través de estudios y propuestas sobre sus estructuras paisajísticas, las percepciones socioculturales y la calificación del paisaje visual.

\section{Palabras clave}

Paisaje cultural. Ordenamiento paisajístico. Ordenamiento territorial.

\section{Put in value of the Santa Teresa Park as a cultural landscape. Project and Ordinance of the Landscape in the General Guidelines of its Master Plan}

\begin{abstract}
The paper is a summary of the landscape studies developed in the framework of 'Lineamientos generales para el Plan Director del Parque Santa Teresa' (General guidelines for Santa Teresa Park Master Plan), agreement made between the Ministry of Tourism, and the Faculty of Architecture, Design And Urbanism of the University of the Republic between August 2015 and July 2016. The purpose of the Convention is to position the Santa Teresa Park as a "model park" for Uruguay, putting in value its patrimonial, landscape and Environmental characteristics, thus contributing to its tourism and sociocultural promotion. The entire project includes and combines different disciplinary studies as well as external contributions. The Research program "Landscape and Public Space" from the Institute of Design in collaboration with VIDIALAB develops the Characterization and Landscape Assessment of the Park, through studies and proposals on its landscape structures, sociocultural perceptions and the qualification of the visual landscape.
\end{abstract}

\section{Keywords}

Cultural Landscape. Landscape planning. Territorial planning. 


\section{Introducción}

La siguiente ponencia constituye una síntesis de las investigaciones y estudios paisajísticos desarrollados en el marco del asesoramiento "Lineamientos generales para el Plan Director del Parque Santa Teresa", realizado por Convenio entre el Ministerio de Turismo (MINTUR) y la Facultad de Arquitectura, Diseño y Urbanismo (FADU) de la Universidad de la República (UDELAR) entre agosto de 2015 y julio de 2016. El objeto del Convenio es posicionar al Parque Santa Teresa como un "parque modelo", referente para todo el país, poniendo en valor sus características patrimoniales, paisajísticas y medioambientales, así como aspectos relacionados a su articulación con otras piezas territoriales de la región, el desarrollo de sus infraestructuras con modalidades sustentables, propuestas inclusivas de comunicación y accesibilidad universal, entre otros.

El Programa de Investigación "Paisaje y Espacio Público" del Instituto de Diseño (IdD) en colaboración con el Laboratorio de Visualización Digital avanzada (VIDIALAB) desarrolla la Caracterización y Valoración Paisajística del Parque. No obstante, el trabajo conjuga estudios académicos de distintos ámbitos disciplinares con aportes externos relevados a través de encuestas, entrevistas y encuentros consultivos, todos ellos orientados a la elaboración conjunta de propuestas de promoción turística y socio-cultural del Parque enmarcadas en una propuesta integral modélica, de lineamientos generales para su Plan Director.

La mirada paisajística entonces, se complementa con otros estudios como por ejemplo: la evolución histórica del Parque y valoración del patrimonio arquitectónico; el diagnóstico arqueológico e identificación de sitios y categorías de conservación; la inserción de la pieza territorial en las dinámicas regionales; el estudio de usos y actividades fundamentalmente en época estival atendiendo a la capacidad de carga del Parque, movilidad y accesibilidad dentro y fuera del mismo, equipamientos turísticos y gestión ambiental de aguas y residuos, recomendaciones de diseño de los elementos e interfases de comunicación e identificación de temas de proyecto.

Los ámbitos de la UDELAR que participan en el trabajo son: el Instituto de Diseño - Paisaje y Espacio público; Diseño y Comunicación - (IdD); el Instituto de Teoría y Urbanismo (ITU); el Instituto de Historia (IHA); el Departamento de Anteproyecto y Proyecto de Arquitectura (DEAPA); el Laboratorio de Visualización Digital avanzada (VIDIALAB) de FADU; la Licenciatura en Diseño de Paisaje (LDP) y Licenciatura en Gestión Ambiental (LGA) del Centro Universitario de la Región Este (CURE) Maldonado y profesores del CURE Rocha y el Instituto Mecánica de los Fluidos (IMFIA) de la Facultad de Ingeniería (FING). Los aportes extra disciplinares, involucran Instituciones públicas y privadas como el Ministerio de Turismo, el Servicio de Parques del ejército (SEPAE) del Ministerio de Defensa, el Sistema Nacional de áreas protegidas (SNAP), organizaciones sociales de la Región, de balnearios aledaños, residentes y visitantes del parque, entre otros.

El equipo responsable del Instituto de Diseño en la Caracterización y valoración del paisaje es coordinado por quien suscribe y está conformado por: Mag. Arq. Norma Piazza, Arq. Rosana Sommaruga y Dra. Arq. Ana Vallarino [responsables], Arq. Graciela Baptista, Bach. José García, Arq. Victoria López Ligerini, Bach. Sofía Massobrio, Arq. Leticia Mora, Bach. William Pérez (Técnico SIG), Dip. Arq. Laura Pirrocco, Arq. Javier Prieto e Ing. Agr. Pablo Ross.

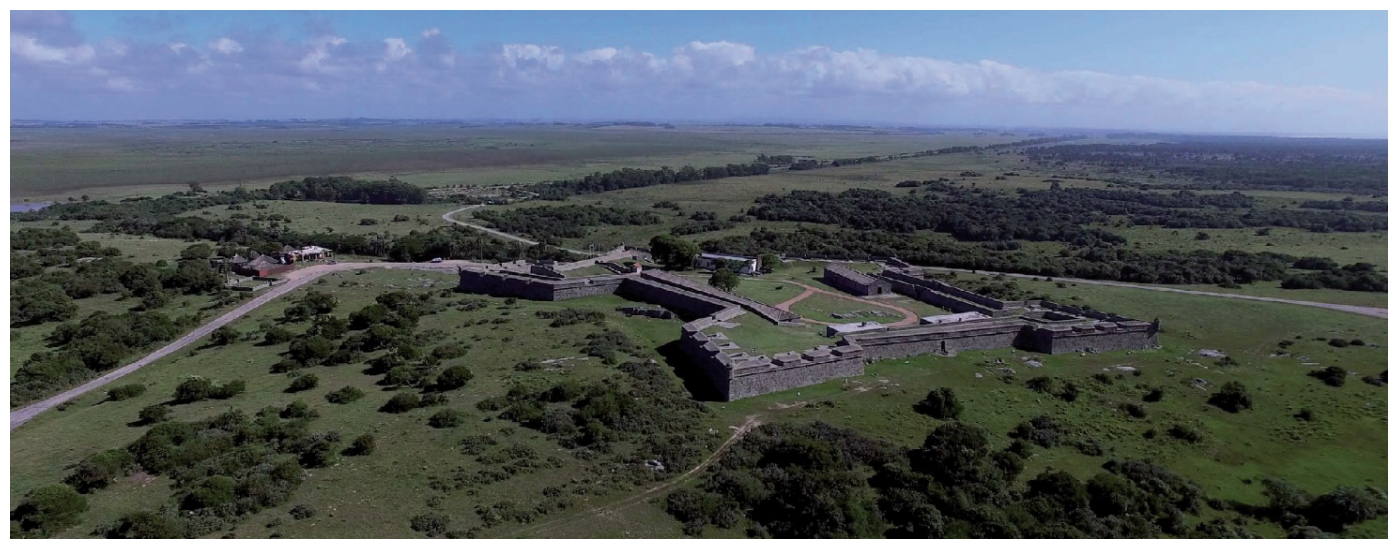

Figura 1. Fortaleza de Santa Teresa. Ubicación estratégica e impronta en el paisaje. Fuente: VIDIALAB. 


\section{La fortaleza como génesis del parque y el proyecto arredondo como génesis del paisaje cultural}

La Fortaleza de Santa Teresa, construida entre 1765 y 1775 en el departamento de Rocha a $302 \mathrm{~km}$ de la capital del país, integra, con el fuerte San Miguel y la Fortaleza General Artigas de Montevideo, un inestimable testimonio de las luchas coloniales por el territorio entre españoles y portugueses. Por su impronta en el paisaje, se comporta como el principal landmark de la región que la singulariza y representa. El Parque, surge en 1920 por iniciativa de Horacio Arredondo que, ante la constatación de su estado ruinoso se propone reconstruirla, escribir su historia y protegerla de los médanos que la sepultaban fijando a éstos con plantaciones forestales. Creado inicialmente para proteger, enmarcar y poner en valor a este monumento, se consolida durante el siglo XX y constituye hoy una pieza territorial de gran escala, conformando uno de los principales parques públicos y equipamientos turístico - costeros del país.
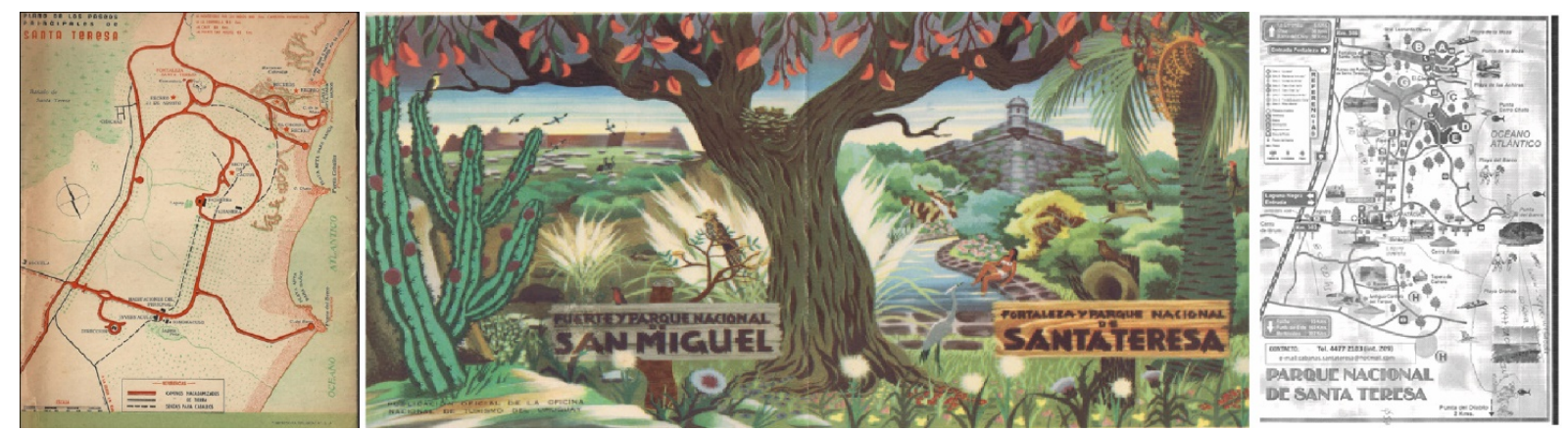

Figura 2. Publicaciones históricas de promoción turística. Fuente: Recopilación y composición de imágenes equipo de investigación

\subsection{La Fortaleza como patrimonio a recuperar / El Proyecto Arredondo}

En 1917, inspirado por la lectura de un texto escrito por Luis Melián Lafinur en 1882 acerca del estado ruinoso en que ya entonces se encontraba la Fortaleza de Santa Teresa, Horacio Arredondo visitó el lugar. Casi sepultada por los médanos, la "pétrea silueta de la construcción militar" se le presentó a la vista en medio de un "panorama desolador": "La impresión que recibí del arcaico monumento fue profunda. Y, "[...] a la vista de ese espectáculo desconsolado, es que se me ocurrió la triple idea de escribir su historia, de reconstruirla y de efectuar la consolidación de los médanos, fijándolos con plantaciones forestales apropiadas" (Arredondo, 1962: 5-6).

Los tres objetivos fueron cumplidos, y el tercero de ellos ampliamente superado por la construcción de un gran parque de 3.000 hectáreas (Torres, 2016: 9).

De esta forma comienza el primer capítulo del trabajo "Lineamientos generales..." nominado: Antecedentes Históricos y da cuenta cabal del origen del Parque Santa Teresa así como también, del carácter temerario de su creador. Las limitaciones para movilizarse desde la capital del país hacia esta región lejana e inaccesible del territorio, los recursos disponibles y las dificultades del momento histórico, permiten imaginar la envergadura de la empresa. Lo ambicioso de la misma se refleja finalmente en la transformación de las plantaciones forestales apropiadas en un proyecto de parque diseñado.

Como Paisajista autodidacta, Horacio Arredondo recoge y suscribe criterios de la época, comúnmente manejados para la creación de parques y jardines. Su proyecto de parque, presenta referencias expresas al estilo apaisado del jardín inglés. Debía realizarse un parque paisajista (Arredondo, 1955) que entre otros aspectos articule las reglas de la perspectiva, ponga en valor la topografía y características del lugar y brinde especial atención a la consideración estética de la selección de especies y agrupamientos vegetales. Por otra parte, dicho estilo principal que daría unidad al conjunto, debería conformarse con sectores y configuraciones diversas que otorgarían variedad al parque. Para ello Arredondo recurre a tres modelos predominantes: el parque umbroso, el parque alegre y el parque pintoresco. 


\subsection{Una propuesta integral / El paisaje cultural}

Los tres objetivos planteados por Arredondo evidencian una manera integral de abordar el problema, donde la revalorización del patrimonio natural e histórico cultural se conjuga con la creación de nuevos paisajes representativos del espíritu de la época. La reconstrucción del relato, la recuperación del monumento y la generación de un parque que lo enmarque y ponga en valor, da cuenta de una temprana conceptualización del paisaje como constructo cultural (Sabaté, 2004). Los objetivos planteados por Arredondo para esta intervención integral, conjugan a su vez distintas consideraciones "paisajísticas" donde la Fortaleza como motivo central del Parque se articula con éste, siendo el mismo, lugar de emociones estéticas y sitio de estudio para naturalistas (Arredondo, 1962).

En particular, la Fortaleza en sí misma, constituye un evento paisajístico indiscutible. A su valor histórico, simbólico y patrimonial, se suma su impronta en el paisaje por su ubicación estratégica, constituyendo a su vez una gran plataforma de acceso visual al territorio. La Fortaleza se comporta como un mojón paisajístico, singular y representativo de la región.

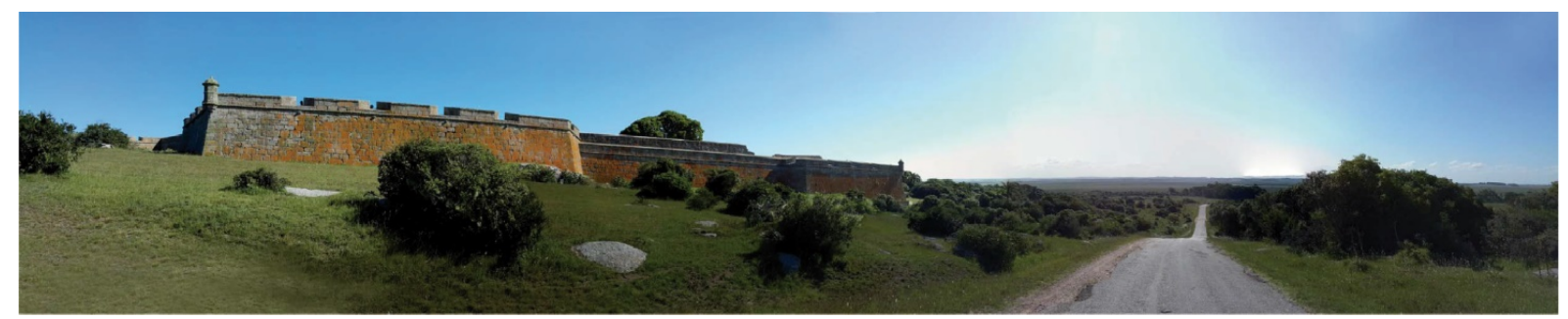

Figura 3 Fortaleza de Santa Teresa. Vista hacia los bañados. Fuente: toma fotográfica equipo de investigación

Los paisajes culturales son ilustrativos de la evolución de la sociedad humana y del uso del espacio a lo largo del tiempo y poseen la capacidad de hacer visibles los elementos culturales esenciales y distintivos de una región (UNESCO, 1998).

Casi 100 años después de la creación del Parque, se plantea un nuevo desafío de revalorizar este rico patrimonio natural, cultural y paisajístico desde el hoy.

La hipótesis de trabajo que orienta la elaboración de los Lineamientos Generales del Plan plantea que: El Parque Santa Teresa reúne las condiciones para convertirse en un Parque modelo de referencia en cuanto al Ordenamiento paisajístico y territorial y la Gestión turística y ambiental a escala nacional. En este marco, se reivindica la pertinencia del concepto de Paisaje cultural para una nueva etapa de revalorización del territorio.

\section{Objetivos generales y específicos}

\subsection{Objetivos generales}

Se plantean entonces, los objetivos generales del trabajo que a modo de Directrices, enmarcarán los objetivos específicos, las líneas de acción estratégicas y recomendaciones. En el presente documento, del conjunto de objetivos generales del trabajo, se hace referencia a los directamente relacionados con los estudios del paisaje. Estos son:

- Revalorizar los elementos históricos patrimoniales y su importancia en la conformación territorial y construcción de identidad a diferentes escalas;

- Reivindicar la condición de constructo cultural del paisaje apostando a la confluencia de saberes y actores territoriales para su construcción colectiva;

- Reconocer la cualidad organizativa de la mirada paisajística a través de la identificación de sus configuraciones y la puesta en valor de sus atributos visuales caracterizadores;

- Promover la consideración del paisaje como materia de proyecto reivindicando su condición proactiva en todas las formas de intervención, ya sean éstas de preservación, transformación o invención. 


\subsection{Objetivos específicos}

En el marco anterior se plantean un conjunto de objetivos específicos de los cuales se destacan:

- La puesta en valor del Parque Patrimonial de Santa Teresa, reconociendo su importancia histórico cultural a escala Nacional;

- La construcción de un Proyecto de paisaje que articule la preservación del legado histórico de Arredondo con representaciones paisajísticas contemporáneas;

- La organización del paisaje en función de un modelo de planificación y manejo alternativo a los habitualmente desarrollados en la faja costera.

\section{La consideración del paisaje cultural en la estrategia teórico metodológica}

Consecuentemente con la idea de paisaje cultural antedicha, se diseña la estrategia teórico metodológica para la Caracterización y Valoración del Paisaje. La misma se conforma por dos etapas fundamentales, la construcción de un marco referencial preliminar y la caracterización y valoración del paisaje propiamente dicha.

En la primera etapa de los estudios preliminares, se construye un marco referencial que incluye el reconocimiento paisajístico general, el análisis de referentes paisajísticos nacionales e internacionales y la realización de encuentros consultivos con el fin de relevar las diferentes ideas de Parque Modelo que poseen los distintos actores y organizaciones involucradas.

El reconocimiento paisajístico general conformado por relevamientos preliminares del sitio y sus principales características así como la sistematización de información secundaria, - fundamentalmente en lo que respecto al análisis y prefiguración del Proyecto paisajístico de Arredondo- se realiza a través de la indagación de documentos escritos por el autor, dado que el plano original no pudo encontrarse en ninguno de los archivos históricos especializados del país.

El estudio de referentes paisajísticos nacionales e internacionales, incluye la consideración del paisaje en las Áreas protegidas ya que si bien el Parque no integra el Sistema Nacional de Áreas Protegidas, tiene múltiples vínculos con importantes áreas del Sistema por proximidad y por ser el mismo Parque plausible de categorización para su preservación.

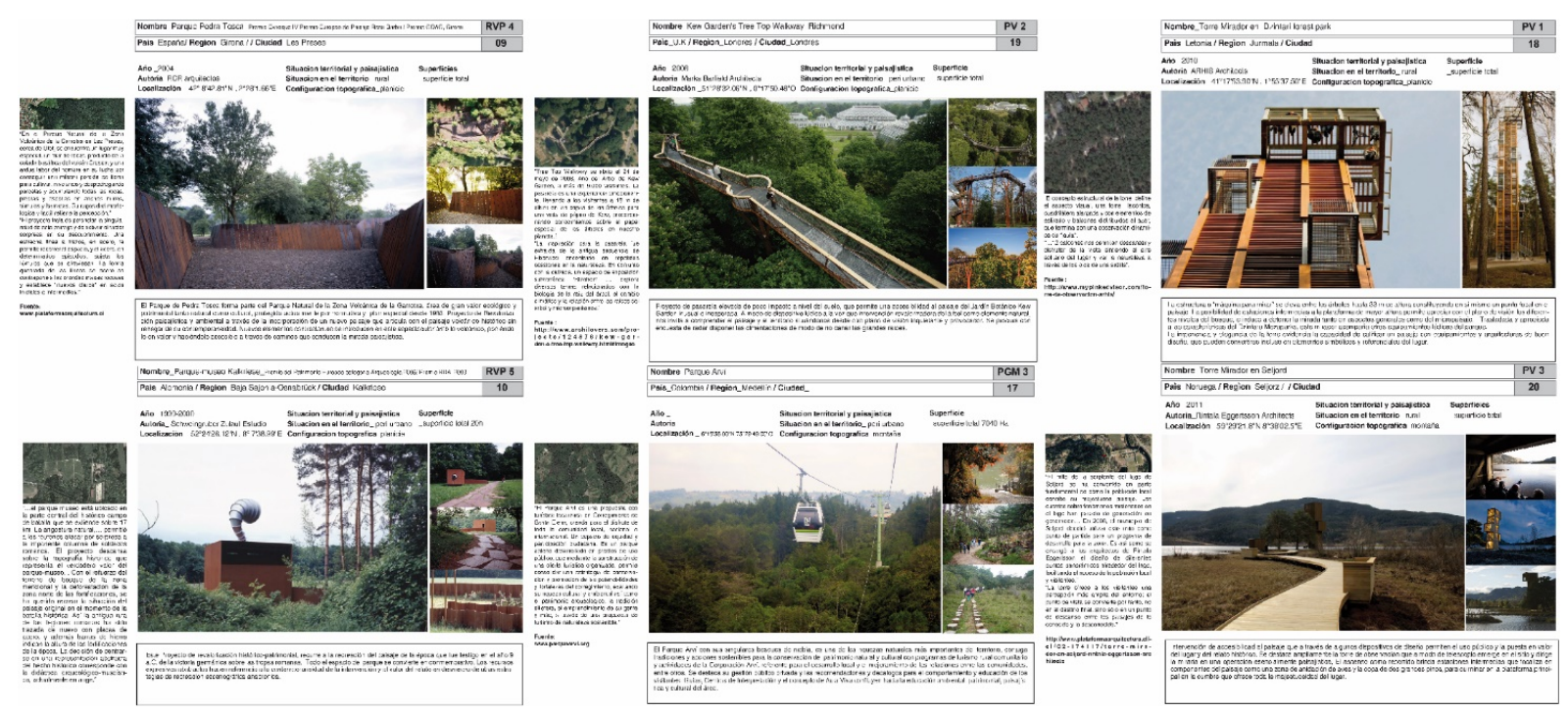

Figura 4. Análisis de referentes paisajísticos nacionales e internacionales. Ejemplos. Fuente: elaboración equipo de investigación.

Por otra parte, el estudio de 24 ejemplos nacionales e internacionales - muchos de éstos premiados en instancias de concursos-, permiten identificar y analizar su excelencia desde el punto de vista del diseño y de la gestión, como sus aciertos sectoriales que evidencian buenas prácticas en distintos componentes del ejemplo. Clasificados en diversas categorías, se seleccionan y anali- 
zan proyectos de restauración o regeneración ambiental y paisajística, donde áreas de riesgo o sitios degradados se restauran y reconvierten en nuevos proyectos de espacio público que brindan servicios ecosistémicos; proyectos de revalorización paisajística y patrimonial donde la preservación y resignificación del patrimonio natural o cultural se convierte en el eje de la intervención; Planes de Protección, gestión y manejo de áreas protegidas, Reservas o áreas naturales como aspectos destacados a analizar y finalmente ejemplos destacados que ponen en valor el paisaje visual a través de arquitecturas y equipamientos que brindan una mayor y mejor accesibilidad al paisaje.

Paralelamente en esta etapa preliminar, se comienzan los encuentros consultivos con distintos actores, organizaciones no gubernamentales, comunidad en general e Institucionales como el propio Ministerio de turismo y el Servicio de Parques y Jardines del Ejército (SEPAE) del Ministerio de Defensa quienes son los gestores actuales del Parque. De esos encuentros se procura establecer las distintas ideas de Parque Modelo de todos los actores involucrados las que se conjugarán a lo largo del trabajo.
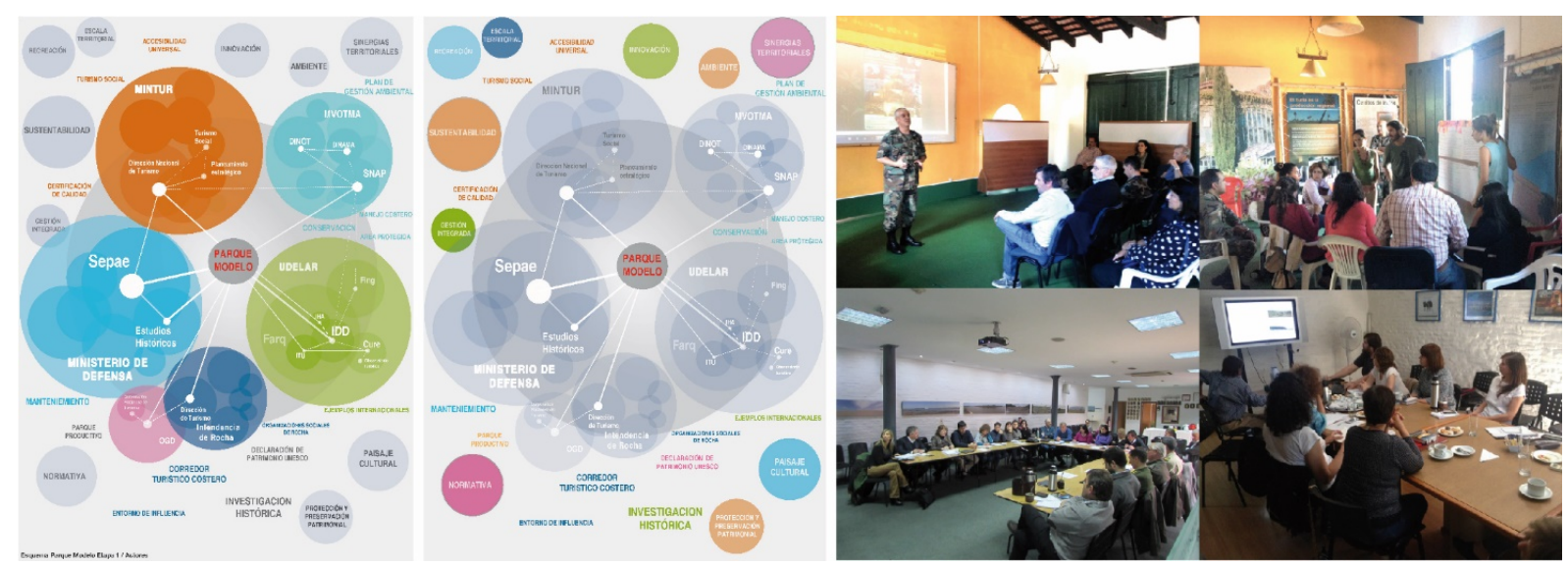

Figura 5. Articulación de temas y actores. Encuentros consultivos. Fuente: elaboración equipo de investigación

En una segunda etapa se desarrolla la Caracterización y Valoración Paisajística del Parque, a través de 3 líneas fundamentales: la identificación de sus estructuras paisajísticas desde el punto de vista del componente vegetal, la identificación de los recursos paisajísticos a través del relevamiento de las percepciones socio culturales y el análisis y valoración del paisaje visual a múltiples escalas.

Estas líneas de trabajo no solo intentan responder a la idea de paisaje cultural en sentido amplio. Atienden fundamentalmente a la propia conceptualización del paisaje a la cual se suscribe, donde la intencionalidad y el reconocimiento del paisaje como constructo signan los trayectos metodológicos. Se entiende al "paisaje como una mirada, una manera de ver y de interpretar..." (Nogué, 2007: 12) así como construcción cultural donde la confluencia de actores y saberes es instancia fundamental.

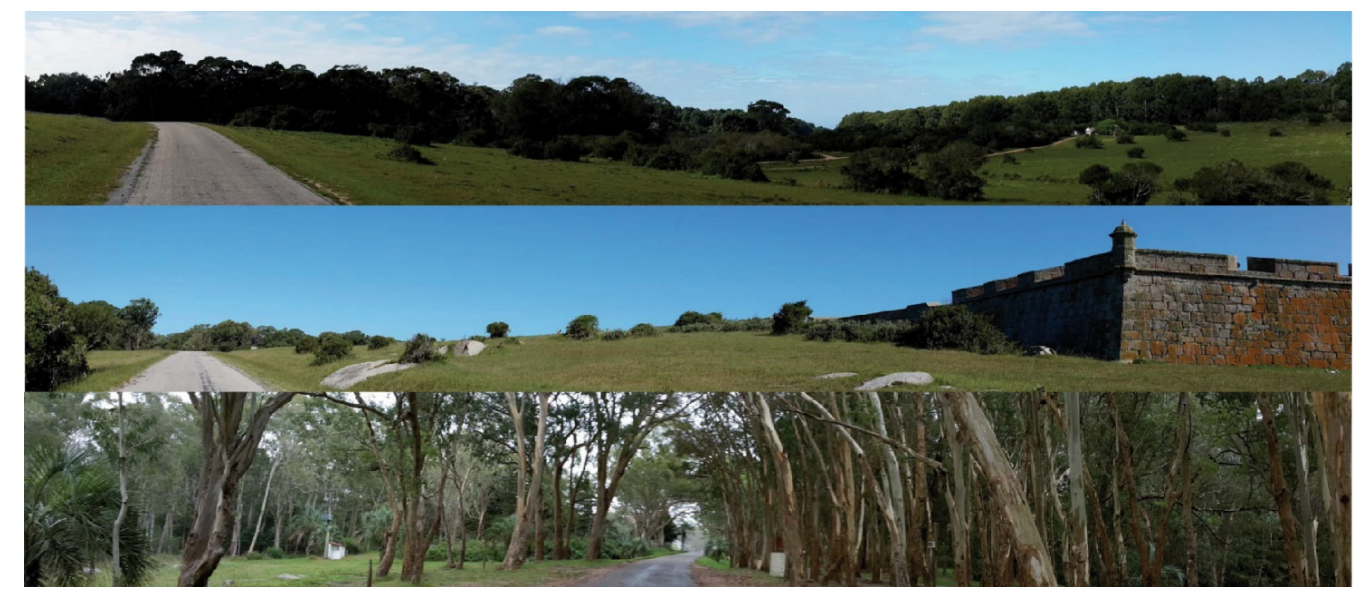

Figura 6. Modelos del Proyecto Arredondo. Parque Alegre. Parque Pintoresco. Parque Umbroso. Fuente: tomas fotográficas equipo de investigación. 


\subsection{Estructuras paisajísticas desde el punto de vista del componente vegetal}

Dado el alcance del trabajo, la gran extensión del Parque y los recursos disponibles, se opta por centrar el análisis en el componente vegetal, y se recurre fundamentalmente a relevamientos de campo así como a la sistematización del material antecedente, realizando avances significativos en el estudio del mismo.

Los relevamientos de campo, permiten el análisis y reconocimiento general de las diferentes áreas del parque y aledaños, donde además de las áreas arboladas, se distinguen las praderas, los bañados y áreas lagunares y la faja costera como hábitat característico y singular. En las áreas arboladas propiamente dichas se diferencian el monte indígena y el bosque forestado principalmente con especies exóticas. Sin embargo, en muchas de estas zonas se presentan composiciones mixtas donde lo exótico convive con lo nativo. De igual forma, en posteriores reconocimientos visuales se identifican las principales configuraciones caracterizadoras del Proyecto Arredondo según los tres modelos que éste propone, el Parque grave o grandioso, el Parque alegre o riente y el Parque Pintoresco.

Por otra parte los relevamientos de campo permiten también, la definición de una cartografía fotográfica perceptual que habilita a vislumbrar la gran riqueza paisajística de su patrimonio natural tanto por las configuraciones de afloramientos rocosos preeminentes en el área, como por la gran diversidad de especies y conformaciones vegetales, poniendo en valor la anatomía artística de los mismos.
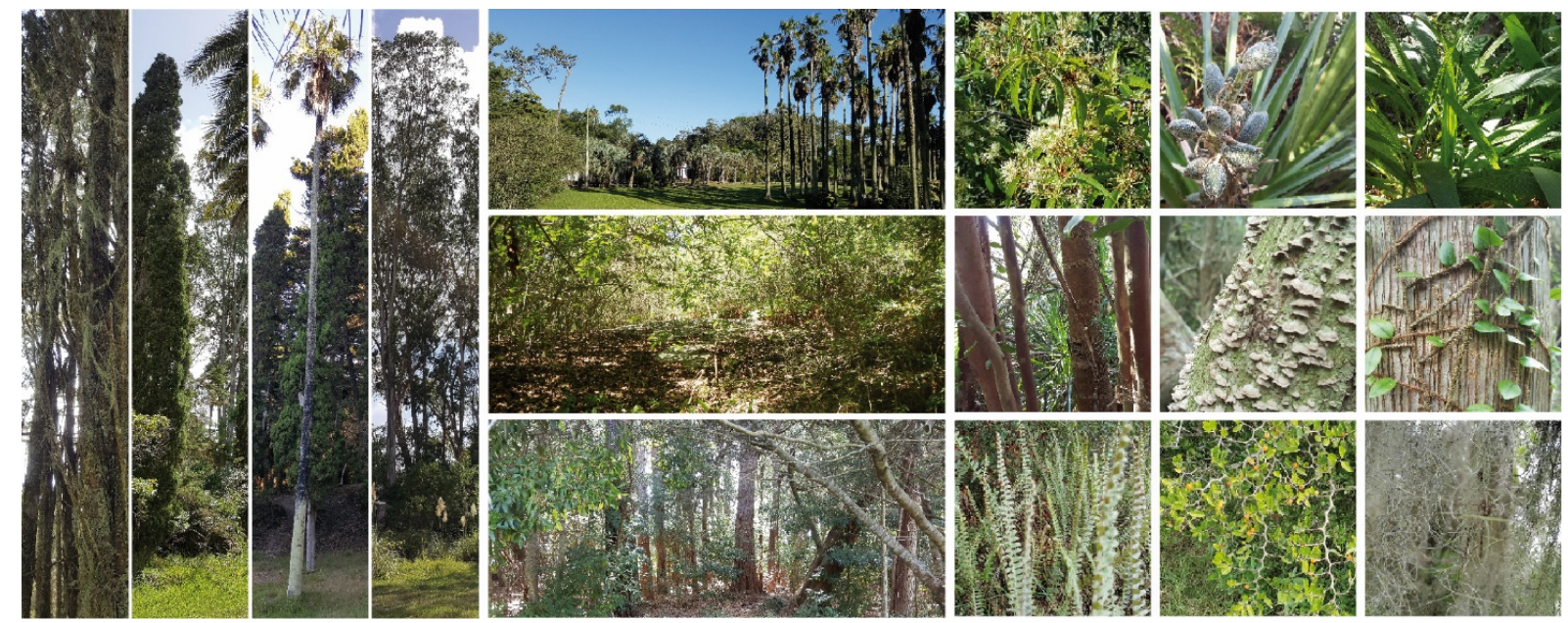

Figura 7. Cartografía fotográfica perceptual. Panorámicas verticales, visuales cercanas y detalles. Fuente: tomas fotográficas equipo de investigación. Informe final.

A su vez la sistematización y organización de la información secundaria permite realizar mapas de agrupamientos vegetales y se basa fundamentalmente en el procesamiento de los relevamientos dendrológicos obtenidos en 1995 por cuatro trabajos de tesis de grado de la Facultad de Agronomía. Se han seleccionado algunas especies y mapeado por áreas, reagrupando algunas de ellas para obtener una cartografía que destaque los sectores de bosque, monte indígena, especies invasoras, coníferas y palmeras.

Esta información se digitaliza a fin de generar insumos imprescindibles para esta etapa de lineamientos y futuras etapas de planificación. De la misma se obtiene: el listado de especies por área y un listado general codificado de especies vegetales, actualizado con verificaciones de campo.

Entre los aportes de la primera línea de trabajo se encuentran, la sistematización y digitalización del relevamiento dendrológico antecedente lo que constituye un primer paso hacia un Inventario general, las recomendaciones hacia un Plan de Gestión Manejo y Mantenimiento del Parque y las pautas para Programas de educación y sensibilización a través de actividades de divulgación, investigación, formación y enseñanza como estrategias principales. Las acciones propuestas se orientan a la realización en futuras etapas de un Inventario vegetal georeferenciado; la creación 
de un Sistema integral botánico - zoológico que, entre otros aspectos plantea retomar la propuesta del Arboretum comenzada en 1954, revitalizar las estructuras existentes del Invernáculo, Sombráculo y Rosaleda y promover la modalidad de Bioparque para el área recreativa existente con animales y pajarera. Complementariamente la reinstalación del Vivero apuesta a un Parque productivo y autosustentable, aprovechando las posibilidades de material proveniente del parque en general, permitiendo la obtención de semillas de calidad para reproducción y sustitución de ejemplares (almácigos, compost) venta, etc.
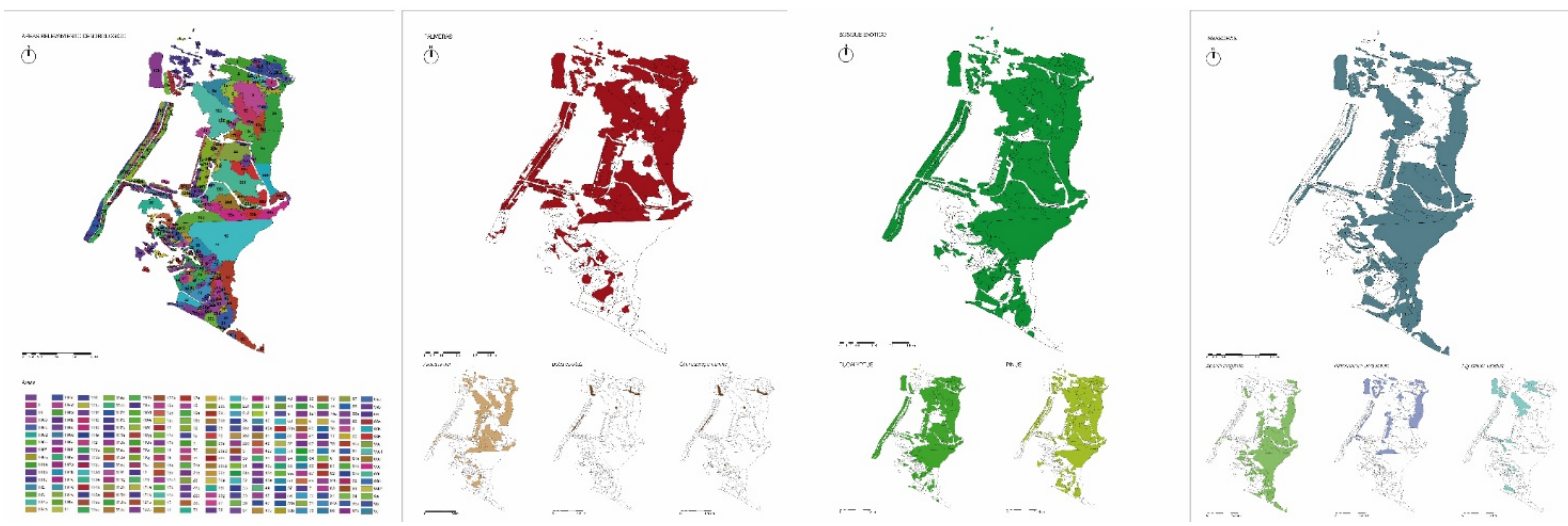

Figura 8. Mapas de Agrupamientos vegetales. Especies por Layers. Fuente: Elaboración de mapas según sistematización de información secundaria. Proyecto SIG. Informe final.

\subsection{Recursos Paisajísticos a través de las Percepciones Socioculturales}

Reivindicando la condición de constructo cultural del paisaje en tanto confluencia de saberes y actores, la segunda línea de trabajo, refiere a la identificación de los recursos paisajísticos a través del relevamiento de las Percepciones Socioculturales, como estrategia para el reconocimiento de fortalezas y potencialidades a través de estas valoraciones.

Entre sus objetivos particulares se pretende: Descubrir cuál es el territorio que los habitantes y usuarios reconocen como parte del Parque; reconocer las preferencias paisajísticas de los habitantes y usuarios del Parque y detectar los componentes más valorados; localizar la distribución de estas preferencias en el territorio, identificar los paisajes percibidos como relevantes para proteger y reconocer futuros deseables, entre otros aspectos. Para ello se diseña un enfoque metodológico combinado entre 3 fases de trabajo: la consulta a actores, desarrollado con estudiantes de la Licenciatura en Diseño de Paisaje LDP; el procesamiento de información proveniente de la promoción turística y el relevamiento de historias del Parque a través de leyendas y representaciones pictóricas y literarias. Esta línea permite entre otros aspectos, la construcción del relato hacia una propuesta de revalorización del paisaje cultural e instalación de nuevos imaginarios.

\subsubsection{Consulta a actores}

Esta indagación exploratoria de percepciones sobre el paisaje se realiza a través de consulta a actores con formato de encuesta. Se desarrolla en el marco de un curso opcional especialmente formulado para tal fin, en el ámbito de la Licenciatura en Diseño de Paisaje del CURE (UDELAR). Este curso se realiza bajo la modalidad de pasantía académica en investigación-extensión, involucra a estudiantes de grado y deviene en la realización de 309 encuestas.

\subsubsection{Relevamiento de elementos identitarios y turístico paisajísticos destacados}

A partir del procesamiento de información proveniente de la promoción turística se identifican los componentes que se valoran y se consideran característicos, identitarios y paisajísticos destacados del Parque Santa Teresa.

Se realiza la búsqueda de material de difusión en versiones papel (folletería) y digital (más de 12 portales web estatales y privados) y se realiza entre otros procesamientos, rangos de preferencia en función de la cantidad de veces que el atractivo turístico es nombrado. 

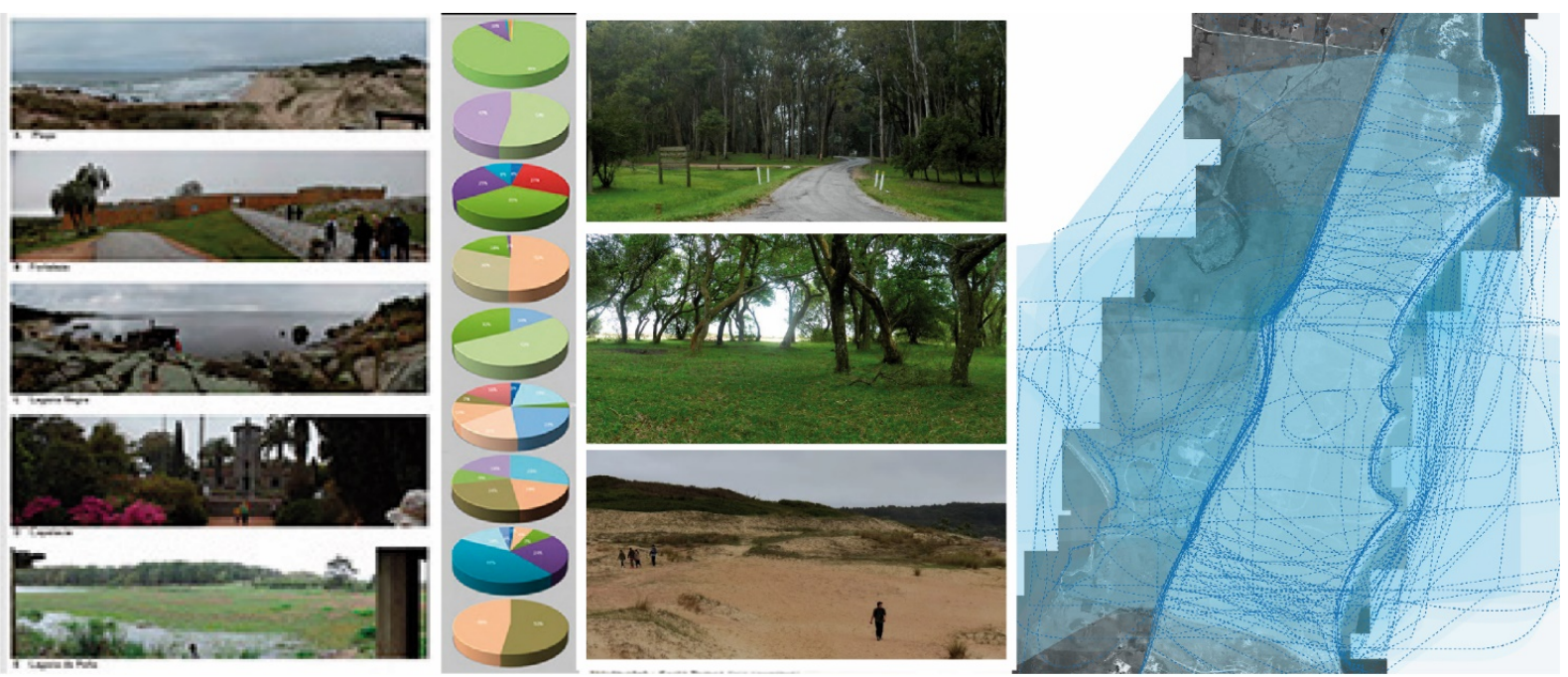

Figura 9. Consulta a actores. Encuesta por preferencia de imágenes. Fuente: Productos del curso opcional de la LDP, Percepciones socio culturales. Caso parque Santa Teresa. Informe final.
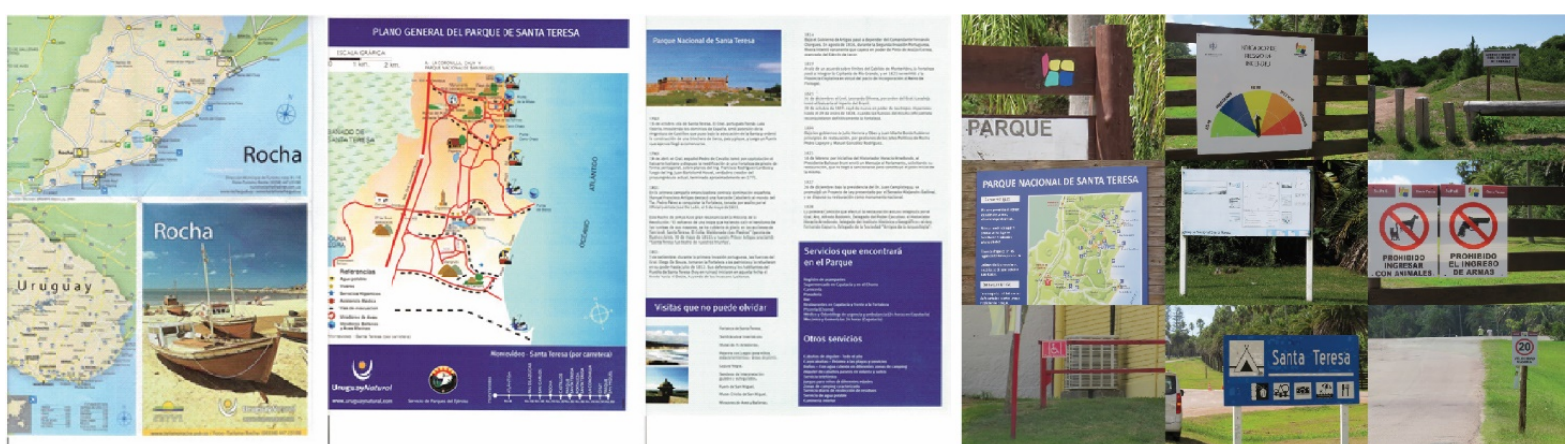

Figura 10 Relevamientos de información turística. Fuente: recopilación de imágenes equipo de investigación. Informe final.

\subsubsection{Percepciones a través de historias, relatos y representaciones}

Relatos, historias y otras representaciones hacen accesible la experiencia del paisaje en tiempos pasados, conectan memorias individuales con memorias colectivas y van más allá de la descripción física poniendo de manifiesto valores estéticos, simbólicos e identitarios del paisaje. Nos comunican el carácter y la esencia del lugar (Piazza, 2014).

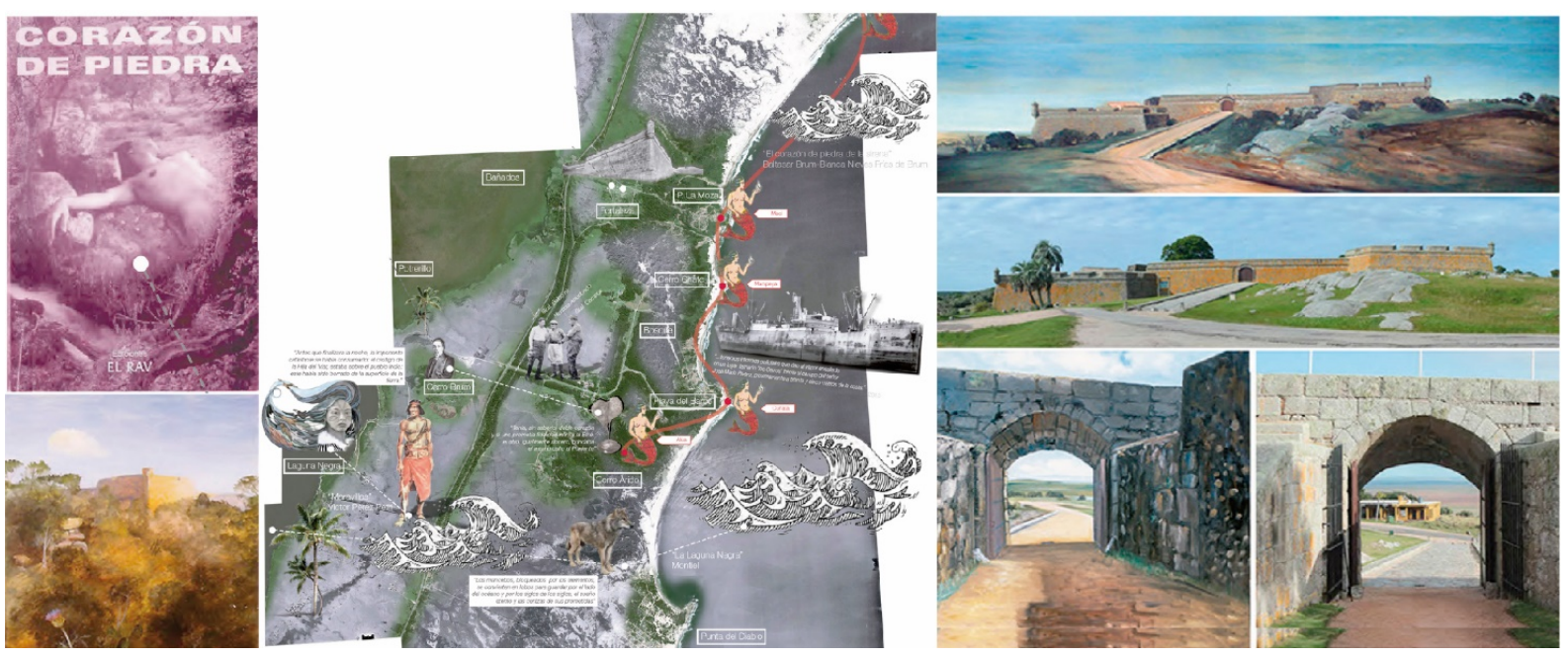

Figura 11. Historias, relatos y representaciones. Fuente: Recopilación y elaboración de imágenes equipo de investigación. Informe Final. 
Se realiza una búsqueda y relevamiento de historias, relatos y representaciones relativas al Parque Santa Teresa en distintas bibliotecas de la Universidad de la República, Biblioteca Nacional, museos y en publicaciones digitales. Los documentos estudiados abordan este paisaje desde las épocas donde el territorio agreste estaba calificado solo por la presencia de la fortaleza, hasta el parque diseñado para el disfrute del patrimonio cultural y natural. Entre ellos se encuentran libros, folletos turísticos de la época y documentos relacionados con el proceso de reconstrucción de la Fortaleza y de construcción del parque.

En esa búsqueda aparecen también expresiones artísticas relevantes, leyendas, relatos de pobladores, cuentos y acontecimientos puntuales que fueron caracterizando este territorio, como las historias fantásticas relacionadas a la creación de la Laguna Negra consecuencia de conflictos entre tribus prehispánicas, los cuentos sobre embarcaciones encalladas, las historias que relacionan las diferentes puntas rocosas de la costa Atlántica con cinco sirenas:

Los espíritus elementales, [...] que poblaban los mares y tierras del viejo mundo, cuando triunfó allá, el cristianismo, emigraron a este continente donde vivieron tranquilos durante varios siglos, hasta presentir que iba a ser descubierto por los cristianos. Cuando esto ocurriera, quedarían privados del único lugar en que podrían vivir en libertad, [...] Una gran asamblea de espíritus elementales del mar y de la tierra decidió la mutación general, en formas recordatorias de sus pasiones [...] Unos, los terrestres, se refugiaron en las flores, en los árboles, peñas, en las aves, insectos, animales; [...]

[...] otras, las marinas, en las costas, cabos, puntas, arrecifes, algas, anémonas, en caracoles, lobos y delfines. Cinco Sirenas, Caaibaté, Maci, Manipeya, Cuñatai y Alúa, que vivían en estos mares, se transformaron, respectivamente, en el Cerro Verde, y en las puntas de la Fortaleza (BRUM, 1963: 9).

El reconocimiento de los elementos paisajísticos más destacados del Parque y la recuperación de representaciones pictóricas y literarias, crónicas históricas, mitos y leyendas permiten la construcción del relato hacia una propuesta de revalorización del paisaje cultural uniendo pasado, presente y futuro.

Las principales recomendaciones que surgen de estos estudios, se centran en:

Planificar procesos de consulta periódicas que garanticen la participación de usuarios y habitantes; preservar las características del parque que trascienden las diferentes épocas identificándose como "inmanentes" y resignificar el paisaje a través de la recuperación de relatos históricos y representaciones paisajísticas singulares como nuevas propuestas de paisaje cultural. (Ej. Itinerarios temáticos, marcas referenciales en el territorio, publicaciones, etc.)

\subsection{Análisis y calificación del Paisaje Visual}

La estrategia que surge de la tercera línea de trabajo, es la recuperación del protagonismo del paisaje visual como atributo lúdico y recreativo de la oferta turística, a través de propuestas que atiendan la diversidad de escalas del paisaje, desde el panorama general al micro escala.

\subsubsection{Registro fotográficos aéreos y estudios de gabinete}

Para este análisis se combinan trabajos de registro y valoración en campo con diversos instrumentos y a distintas alturas de apreciación, con métodos de construcción de Cuencas Visuales en gabinete a través de técnicas de visualización digital avanzada, lo que permite relacionar de modo interescalar las diferentes visualizaciones del territorio.

Lo anterior, posibilita descubrir los aportes singulares de cada lectura y coadyuva a una mejor comprensión del paisaje en general y a la identificación de sus principales recursos y fortalezas escénicas.

Para la definición de cuencas visuales, se recurre a la modelización del territorio a partir de las curvas de nivel y la modelización de las masas vegetales en conjunto con la analogía entre zonas “iluminadas" y áreas de visión asignando el rol de foco luminoso al punto de interés. 


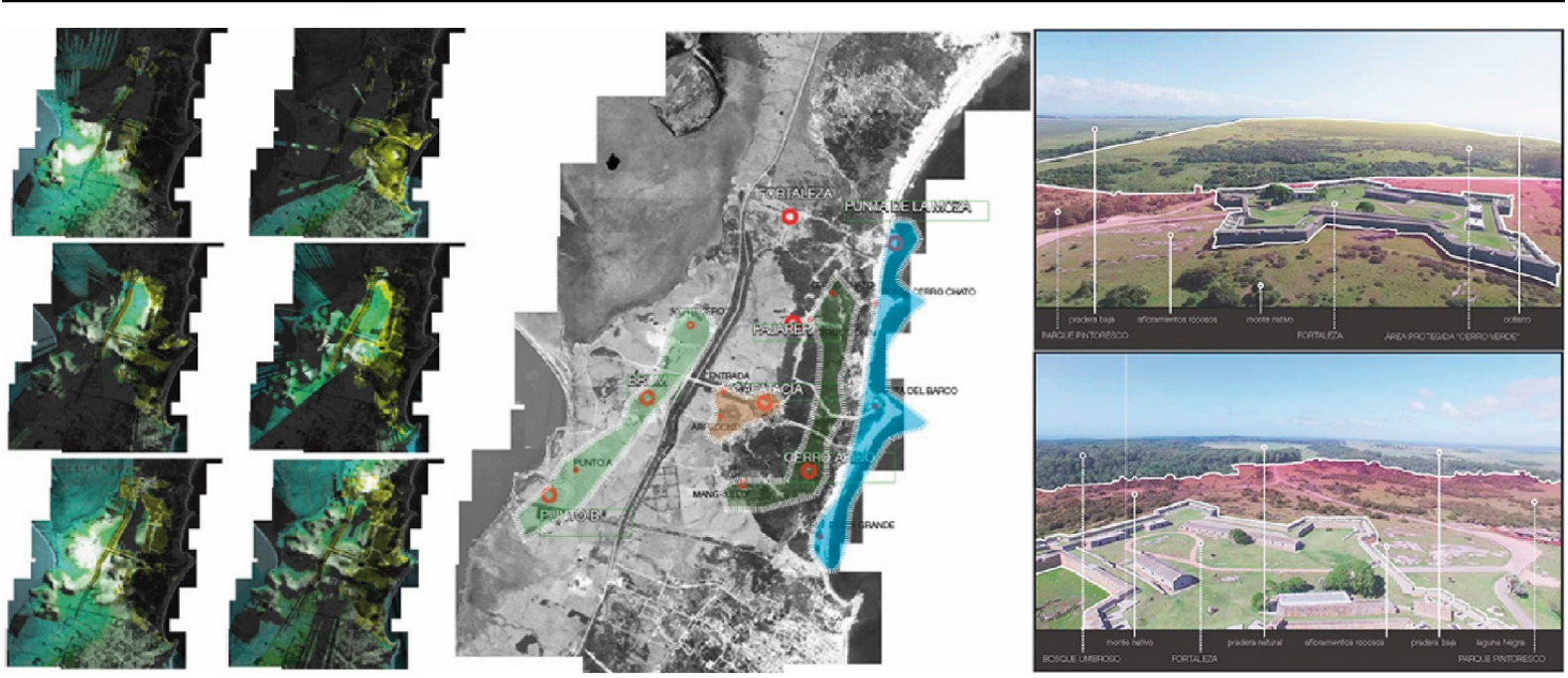

Figura 12. Cuencas Visuales de gabinete. Puntos excepcionales. Identificación de componentes del paisaje.

Fuente: Elaboración de imágenes equipo de investigación y Vidialab. Informe final.

Con relación a los registro de campo, se recurre al análisis de las lecturas de visión vertical, y al registro aéreo panorámico por drones, para la valoración del macro paisaje a distintas alturas $(12-40 \mathrm{~m})$.

A través de los drones se registran y analizan 17 puntos del Parque, se agrupan según comportamientos visuales equivalentes y se seleccionan 6 puntos excepcionales y representativos, identificando los principales componentes del paisaje. Estos puntos, conjuntamente con los miradores ya existentes permitirán definir una serie de propuestas que van desde figuras de protección para los mismos hasta programas de promoción del paisaje visual.

\subsubsection{Análisis y calificación visual a horizonte normal}

Complementariamente se realizan relevamientos y calificaciones de visión a horizonte normal, desde los caminos y Avenidas del Parque por ser éstos los sitios y áreas públicas que posibilitan la accesibilidad visual al mismo. De este análisis se identifican las configuraciones singulares del Parque de menor escala y la verificación de las visiones de gabinete.

Se identifican tramos, nodos y áreas, clasificando a los mismos según tipo de vistas, alcance visual, definición espacial, bordes y trazados predominantes. También se reconocen los modelos referentes según el Proyecto Arredondo (Parque umbroso, Parque alegre y Parque pintoresco) considerando la percepción desde las avenidas y caminos.
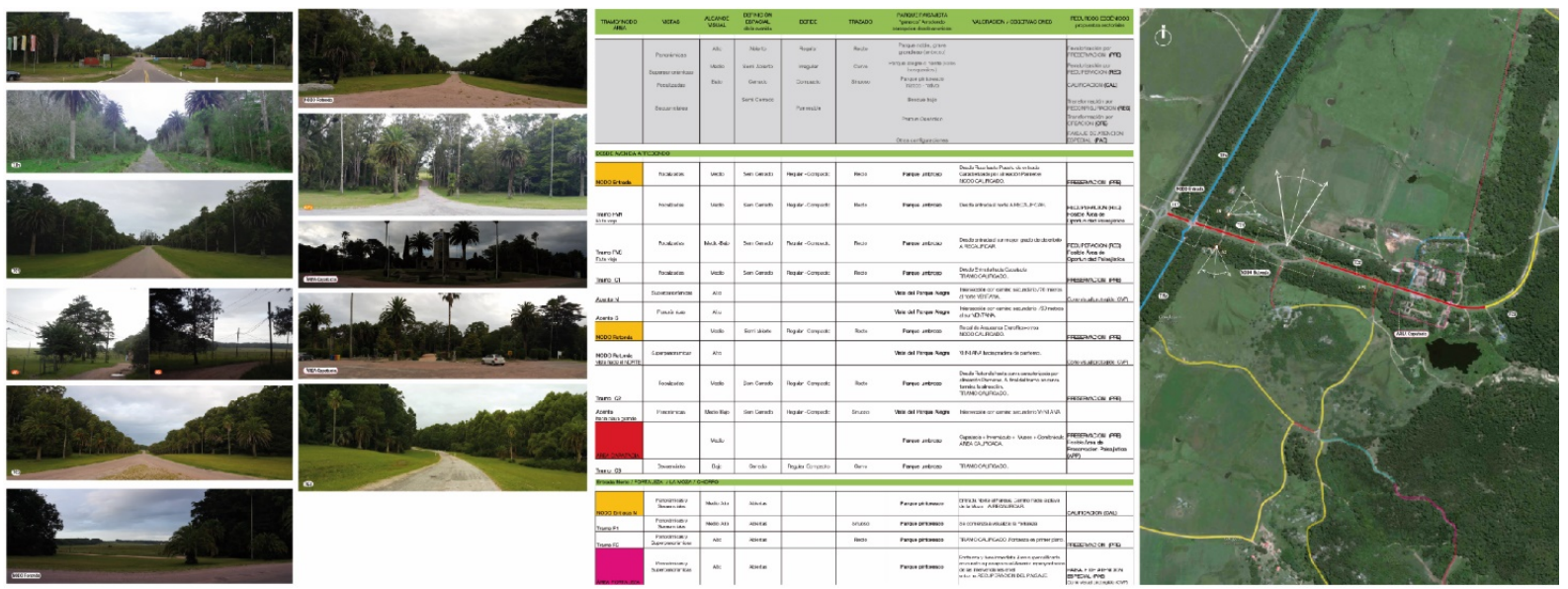

Figura 13. Análisis y calificación del paisaje visual desde horizonte normal. Registros fotográficos. Identificación de sectores. Fuente: Elaboración de imágenes equipo de investigación. Informe final. 
Finalmente se realiza la valoración sectorial de cada entidad y se plantean estrategias de intervención en función de su carácter, situación y potencialidad paisajística en relación al Parque todo. Se plantean 5 categorías básicas de intervención en esta escala: revalorización por preservación, revalorización por recuperación, calificación del espacio público, transformación por reconfiguración y transformación por creación de nuevos paisajes.

Estos estudios permiten identificar las principales características del paisaje visual del Parque así como su macrescala como atributo fundamental. De ellos se desprende recomendaciones y propuestas enmarcadas en el Programa integral de revalorización de las visuales: "Máquinas de mirar" a través de la combinación de instrumentos físicos y virtuales y modalidades tradicionales y no convencionales. Entre otros:

- Promover la visualización de la macroescala del Paisaje a través de modalidades no tradicionales e interfases tecnológicas que permitan al visitante la apreciación de la principal característica del Parque que lo singulariza. (Portales web, casquetes 360 de navegación interactiva, etc.).

- Identificación de visuales panorámicas y superpanorámicas con el fin de preservar el paisaje visual como recurso, poniendo en valor perspectivas y vistas excepcionales del Parque. (Itinerarios de visuales).

- Proyectar equipamientos específicos para tal fin, potenciando el carácter lúdico de los mismos y las sinergias posibles de su definición como sistema integral, modalidades tradicionales (sistema de miradores y pasarelas elevadas).

- Recuperar las intervisibilidades estratégicas entre los principales estructuradores del paisaje del Parque. Proyecto recuperación de abras.

- Promover Programas de eventos y actividades deportivas y recreativas que posibiliten accesibilidad al paisaje de forma singular fundamentalmente del conjunto del Parque, Laguna Negra y Áreas protegidas modalidades no tradicionales temporales (globos aerostáticos, parapentes, paramotores).
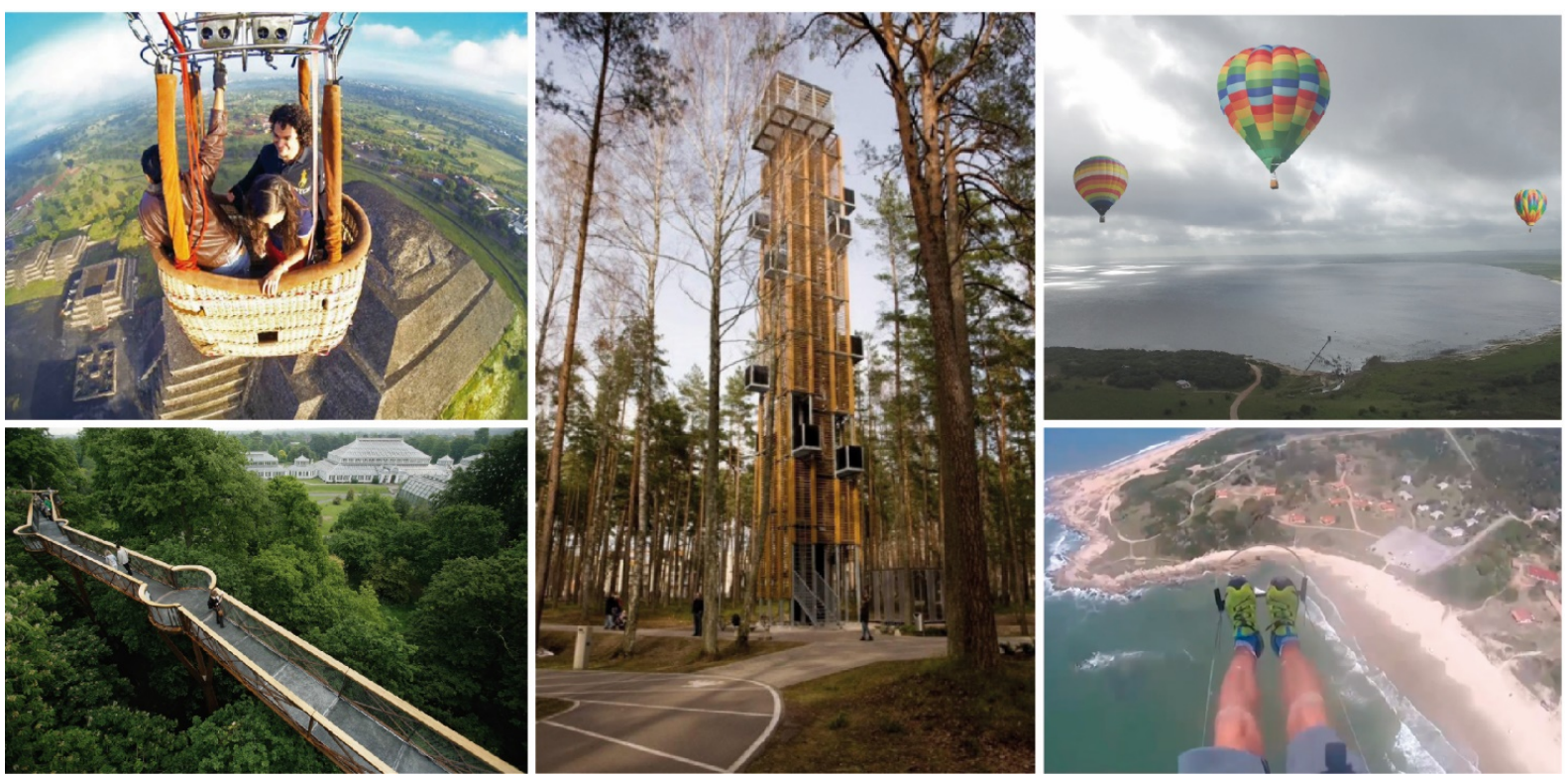

Figura 14 "Máquinas de mirar". Referentes internacionales. Simulaciones en Laguna Negra. Paramotor sobre Playa del Barco. Fuente: Recopilación de imágenes equipo de investigación. Informe final.

\section{Lineamientos y propuestas hacia un plan de ordenamiento paisajístico del parque}

En el marco de la hipótesis y objetivos del trabajo, así como de los estudios preliminares y desarrollos en profundidad, se delinean una serie de estrategias y recomendaciones que promoverán tanto acciones a escala macro atendiendo a una concepción integral del Parque como pautas de acción para los principales temas específicos, ya explicitados. De igual modo, todas estas propuestas deben conjugarse en una idea integral de ordenación que defina estrategias proyectuales generales, que las articule y genere las sinergias necesarias y organice los lineamientos de forma coordinada. 
Dada la diversidad del Proyecto, y con el objetivo de una mejor lectura integral de las propuestas sectoriales ya descriptas, en el siguiente apartado se presentan las principales estrategias que enmarcan las recomendaciones y agenda de temas. Por la extensión de éstas últimas, solo se enumeran, a modo de ejemplo, algunas de las recomendaciones más importantes.

Hacia el cumplimiento del objetivo "Puesta en valor del Parque Patrimonial de Santa Teresa, reconociendo su importancia histórico cultural a escala nacional", las principales estrategias definidas son:

- La recuperación de la idea original de Arredondo en relación al sistema complementario de parques y fortalezas considerando el par Santa Teresa - San Miguel. Promover el conocimiento y la lectura conjunta entre los parques y a la complementariedad definida entre "Parque Turístico y Parque Criollo";

- Y la revalorización del Monumento de la Fortaleza propiciando entre otros aspectos, nuevas formas de comunicación del relato histórico según tendencias museísticas contemporáneas y reposicionando la relación ente la Fortaleza y el Parque, para evidenciar su posición estratégica como mojón paisajístico y permear su presencia en la malla del mismo.

Entre las principales estrategias orientadas al cumplimiento del objetivo "Construcción de un proyecto de paisaje que articule la preservación del legado histórico de Arredondo con representaciones paisajísticas contemporáneas" se definen:

- Preservar la configuración general del Parque verde de gran escala, promoviendo intervenciones puntuales y concentradas; acciones de bajo impacto a escala general ya sean éstas en modalidad de islas o en modalidad de mallas en la superficie del Parque.

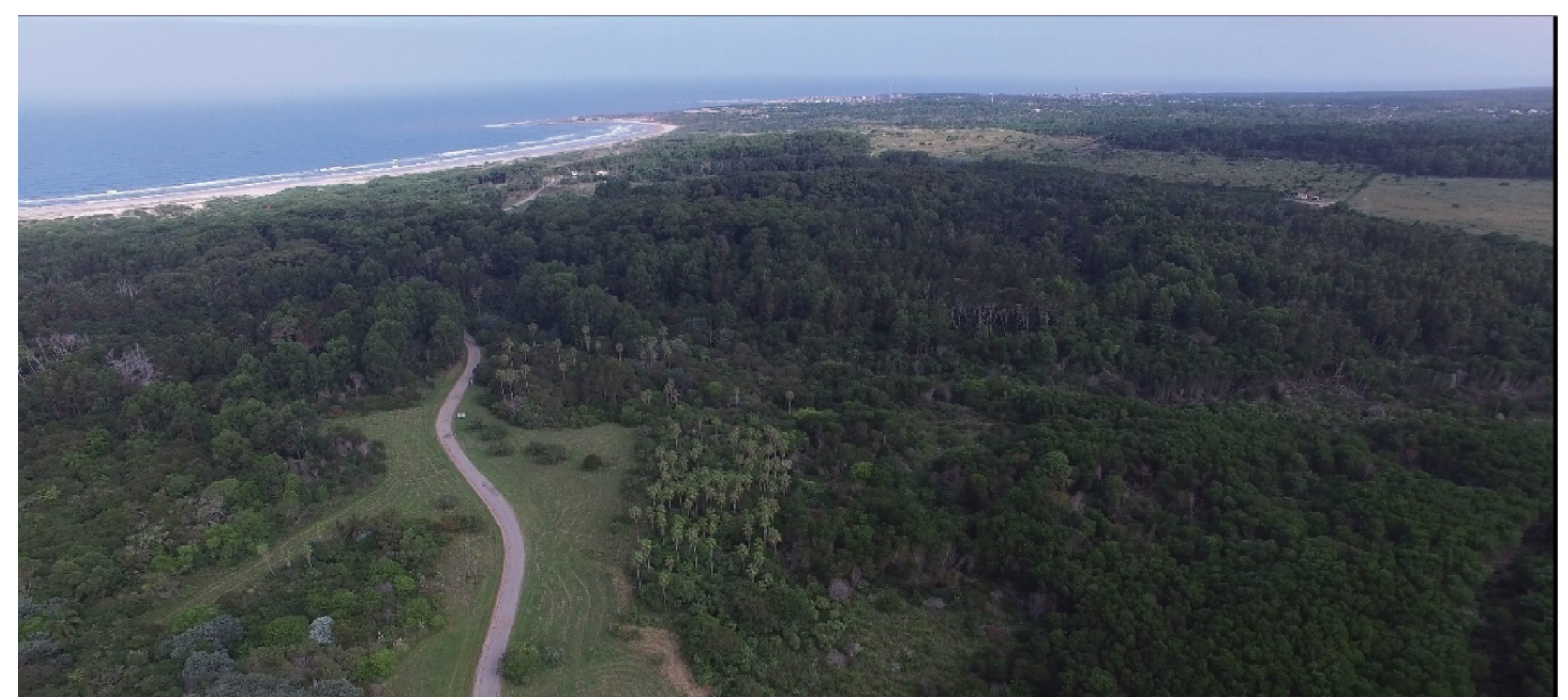

Figura 15. La macro escala del paisaje. Fuente: VIDIALAB.

- Puesta en valor de las ideas paisajísticas del Proyecto Arredondo, identificando sus configuraciones caracterizadoras del Parque: el Parque grave, alegre y pintoresco, evaluando su permanencia, transformaciones y pertinencia actual. Reafirmar los principales estructuradores del Parque y definir Áreas de preservación paisajística (APP) como acciones prioritarias que eviten la continuidad de las alteraciones actuales.

- Promover nuevas representaciones paisajísticas que reinstalen al Parque Santa Teresa en el imaginario socio cultural contemporáneo, a través de: nuevas propuestas, actividades turísticas y programas lúdico recreativos que coadyuven a construir nuevas imágenes paisajísticas referentes así como recuperar viejos relatos, definir programas educativos y de investigación que promuevan el conocimiento de estos paisajes e identificar Áreas de Oportunidad Paisajística (AOP), nuevas intervenciones potenciales en el Parque. 
Se reconoce de esta forma las tres etapas fundamentales en el devenir del paisaje del Parque: el paisaje primigenio, el proyecto Arredondo y el Parque contemporáneo, promoviendo la idea de constructo cultural y colectivo.

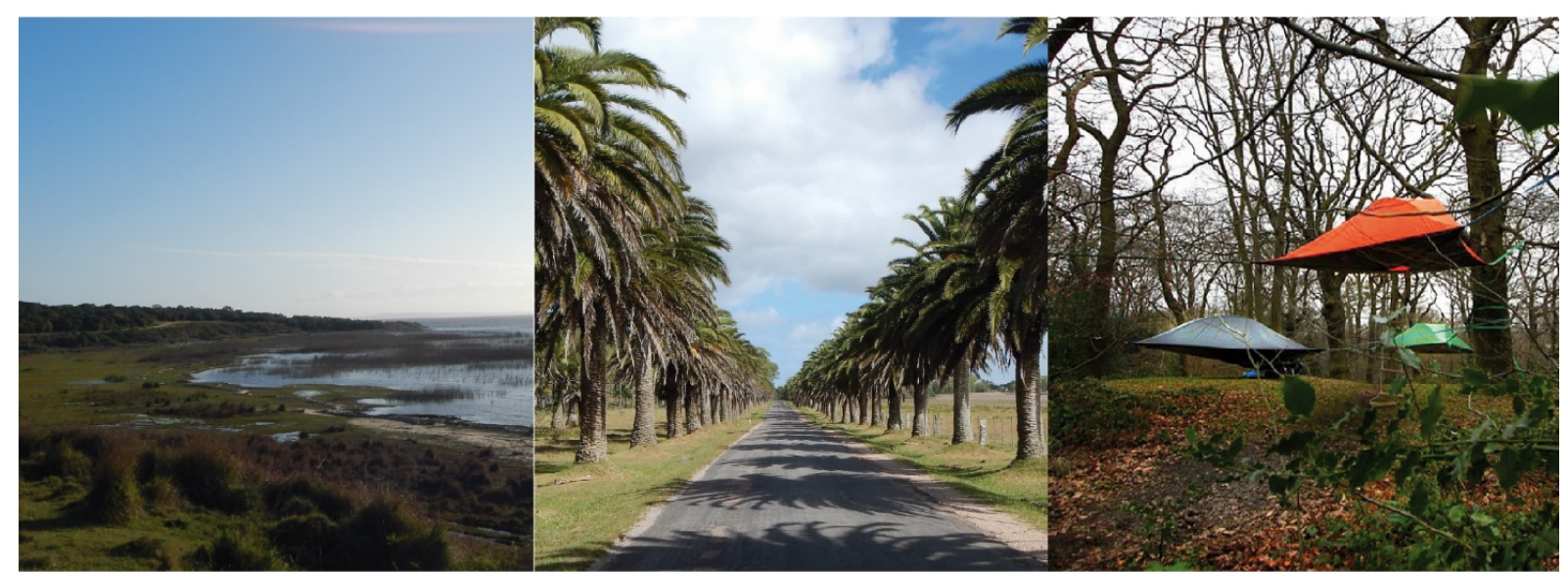

Figura 16. Reconocimiento de etapas fundamentales del Parque. Paisaje primigenio, Proyecto Arredondo, paisaje contemporáneo. Fuente: Tomas fotográficas y recopilación de imágenes equipo de investigación. Informe final.

Dentro de las estrategias sectoriales definidas para este mismo objetivo se recuerdan las principales:

- Promover un conjunto de acciones hacia la elaboración de un Plan de gestión, manejo y mantenimiento del Parque, continuando la sistematización de información hacia un Inventario vegetal georeferenciado y la recuperación del Proyecto Vivero para la reproducción e investigación entre otros.

- Promover Programas de educación y sensibilización de usuarios y funcionarios que entre otros aspectos, articule la exposición, conservación, investigación y enseñanza.

- Atender las valoraciones y percepciones socio culturales de modo de reconocer de forma colectiva, fortalezas y potencialidades del Parque, planificado procesos de consulta periódica y recuperando relatos históricos y representaciones paisajísticas singulares entre otros aspectos.

- Recuperar el protagonismo del paisaje visual como atributo lúdico y recreativo de la oferta turística a través de propuestas específicas que atiendan la diversidad de escalas del paisaje, desde el panorama general a la microescala, a través del Programa integral "Máquinas de mirar" que incluye entre otros, plataformas interactivas web, itinerario de visuales, sistema de miradores y pasarelas, actividades deportivas que coadyuven a una singular accesibilidad al paisaje, etc.

Con relación al cumplimiento del objetivo: “Organización del paisaje en función de un modelo de planificación y manejo alternativo" se define promover el desarrollo de un modelo de planificación y manejo alternativo - "anti modelo" - a la planificación tradicionalmente desarrollada en los ámbitos costeros considerando las particularidades de las Áreas Protegidas así como la accesibilidad controlada a la faja costera.

En síntesis, desde el punto de vista del Ordenamiento paisajístico, se georeferencian una serie de propuestas sectoriales de revalorización o transformación. En función del Mapa Síntesis de valoraciones paisajísticas se construye un Mapa de Áreas de Ordenación Paisajística e identificación de proyectos con el fin de conjugar las propuestas sectoriales y promover figuras específicas a contemplar en futuras etapas de planificación. Las mismas son: Área de preservación paisajística (APP) (medida cautelar); Área de Reconfiguración Paisajística (ARP); Área de Oportunidad Paisajística (AOP); Paisaje de Atención Especial (PAE); Perímetros de Protección (PPP) (medida cautelar); Conos Visuales Protegidos (CVP) (medida cautelar); entre otros. 


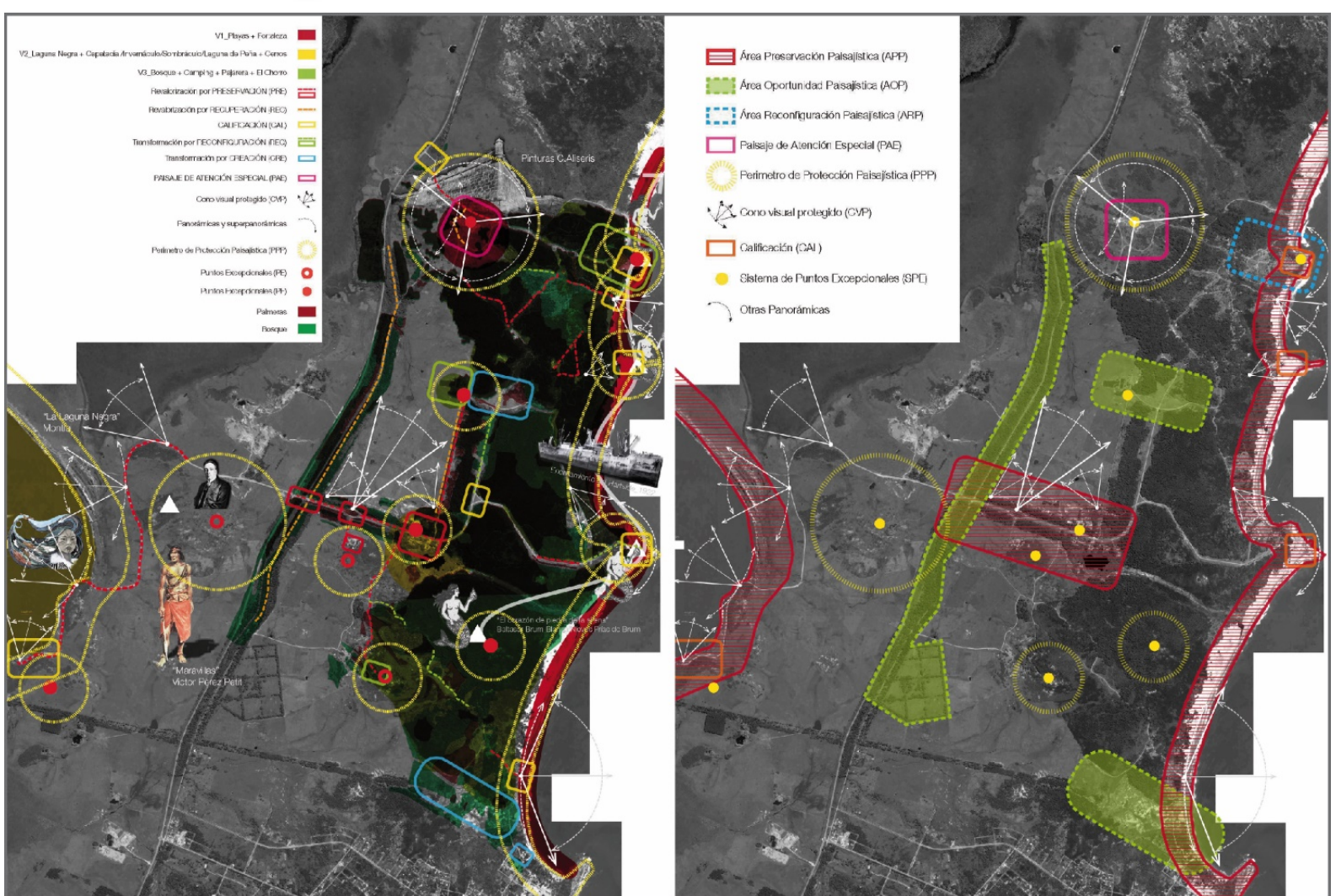

Figura 17. Mapa de Valoraciones Paisajísticas. Propuesta de Áreas de Ordenación paisajística. Fuente: Elaboración equipo de investigación. Informe final.

\section{Consideraciones finales}

Realizar una propuesta sobre el Parque Santa Teresa ha posibilitado reflexionar sobre las condiciones y atributos de un Proyecto de Paisaje y reivindicar ciertas posturas teórico conceptuales que se consideran pertinentes.

La construcción de un Proyecto de paisaje que procura articular los diferentes momentos históricos del mismo, permite poner en valor la condición de palimpsesto del territorio y la cualidad de la mirada paisajística para su lectura y reconocimiento.

En segundo lugar, la reivindicación de la condición de constructo cultural y colectivo del paisaje, contribuye a evidenciar los esfuerzos históricos para su construcción, interpretación y preservación así como promueve y orienta los nuevos procesos de apropiación.

Por último, si bien en muchos casos los proyecto de paisaje requieren de importantes operaciones de transformación, en algunos otros las prioridades se orientan a la recuperación de representaciones y valores olvidados, la sistematización de valiosos estudios antecedentes, la revalorización cuidadosa de lo existente así como también la incorporación de nuevas acciones y figuraciones que reflejen el sentir de la sociedad contemporánea. Un Proyecto de paisaje puede solamente promover "descubrir" y "evidenciar" sus valores inmanentes, promover nuevas y novedosas formas de "mirar" y así solamente, revalorizar desde el hoy.

Desde el punto de vista conceptual y procurando ser fieles a su tiempo, estas formas de intervención en el paisaje, aún sin grandes impactos en el territorio, permiten orientan acciones de ordenación y propuesta, y coadyuvar a la refundación cultural y reafirmación de la identidad, aportando de esta forma a las nuevas construcciones de los imaginarios colectivos.

El desarrollo general del trabajo permite validar la hipótesis inicialmente planteada. No solamente se verifican las condiciones del Parque Santa Teresa para convertirse en un Parque modelo de referencia a escala nacional en cuanto al Ordenamiento paisajístico y territorial, sino 
también se reafirma el encuadre teórico metodológico del trabajo. La pertinencia del concepto de Paisaje cultural para una nueva etapa de revalorización del territorio, así como una visión proyectual que oriente los lineamientos generales del Plan, coadyuvará al desarrollo de futuras etapas de ordenación asegurando una visión paisajística contemporánea que articule preservación e invención de nuevos paisajes.

\section{Referencias}

Arredondo, H. (1962). Parques nacionales. Los nuestros - perspectiva universal-directivas. Montevideo: Dirección de parques nacionales de Santa Teresa y San Miguel.

Arredondo H. (1955). Santa Teresa y San Miguel. La restauración de las fortalezas. La formación de sus parques - Tomo XIII. Revista de la Sociedad "Amigos de la Arqueología". Biblioteca Facultad de Humanidades, Colección Arredondo. (Montevideo).

Biraben, J., Crocci, R., Gómez, A., Malmierca, P., O'neill, M., Puppo, H., \& Ruvira, F. (1995). Relevamiento dendrológico del parque Santa Teresa. Tesis de grado, Tomo I (Dirección: C. Brussa, C. Sans, \& J. M. Pouso). Montevideo, Facultad de Agronomía, Universidad de la República.

Biraben, J., \& Crocci, R. (1995). Relevamiento dendrológico del parque Santa Teresa. Tesis de grado, Tomo IV (Dirección: C. Brussa, C. Sans, \& J. M. Pouso). Montevideo, Facultad de Agronomía, Universidad de la República.

Brum, B. (1963). En Algunas páginas de su Libro de Honor. Montevideo: Comisión Honoraria Administradora Parque Santa Teresa.

Bureau of Land Management - United States Department of the Interior. Manual 8431 - Visual Resource Contrast Rating. Disponible en: http://www.blm.gov (Consulta: 20/5/2015).

FADU, Instituto de Diseño (2016). Lineamientos Generales para el Plan Director del Parque Santa Teresa. Informe final. Disponible en: http://www.fadu.edu.uy/idd/programas-de-investigacion-permanente/ paisaje-y-espacio-publico/ (Consulta:12/11/2016).

FADU, Instituto de Diseño (2006). Pautas para el ordenamiento paisajístico de la rambla de Montevideo. Montevideo: IMM-UdelaR / Facultad de Arquitectura.

Galofaro, L. (2003). Artscapes. El arte como aproximación al paisaje contemporáneo (Land \& Scape Series). Barcelona: Gustavo Gili.

Muñoz, J., Ross, P., \& Cracco, P. (1993). Flora indígena del Uruguay. Árboles y arbustos ornamentales. Montevideo: Editorial Agropecuaria Hemisferio Sur S.R.L.

Nogué, J. (2007). La construcción social del paisaje. Madrid: Biblioteca Nueva.

Nogué J., Puigbert, L., \& Gemma, B. (2009). Plecs de paisatge: Elines 2. Ordenació i gesti ó del paisatge a Europa. Barcelona: Ed. Observatorio de Paisaje de Catalunya.

Sabaté Bel, J. (2004). De la preservación del patrimonio a la ordenación del paisaje. Urbano, [en línea]. Año 7. № 10, 42-49. Disponible en http://www.redalyc.org/comocitar.oa?id=19871009 (Consulta: 10/10/2015).

Sabaté Bel J. et al. (Coords.) (2012). Paisajes culturales en Uruguay. Laboratorio Internacional de Paisajes Culturales. Revista Identidades: territorio, proyecto, patrimonio, 3.

Sommaruga, R. et al. (Coords.) (2010). La frontera del Agua. El paisaje costero del Uruguay. Montevideo. Universidad de la República, Facultad de Arquitectura, Instituto de Diseño - Intendencia Municipal de Montevideo - Ministerio de Vivienda, Ordenamiento Territorial y Medio Ambiente - Junta de Andalucía.

UNESCO (1998). Convención de patrimonio Mundial. Disponible en: http://portal.unesco.org/es/ev.php Consulta: 9/6/2015). 